Savunma Bilimleri Dergisi

The Journal of Defense Sciences

Mayıs / May 2021, Say1/Issue 39.

ISSN (Bas1l1) : 1303-6831 ISSN (Online): 2148-1776

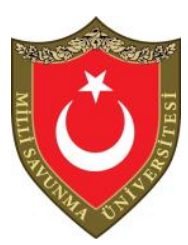

\title{
Seramik Ön Yüzlü Çelik Zırhlarda Balistik Hasar Sonrası Çelik Kısmında Oluşan Deformasyonun İncelenmesi
}

\author{
Barış KALAYCIOĞLU* ve Alemdar ONGUN**
}

$\ddot{O} z$

Günümüzde birçok çalı̧̧ma konusunda olduğu gibi, zırh tasarımında da sayısal analizler, balistik deney imkânlarının azlı̆̆ı ve bir hayli maliyetli olması sebebiyle öncelikli olarak tercih edilir hale gelmistitir. Ancak sayısal analizler ile deneysel sonuçların örtüşmesi, sayısal analizlerin doğrulanması açısından oldukça önemlidir. Bu çalışmada, uygun malzemelerle gelişsirilmişs seramik ön yüze sahip çelik zırh sisteminin 7,62 mm kalibreli mermi darbesi sonucu arka yüzeyindeki çelik plakada oluşan plastik deformasyon durumu analitik ve sayısal analizler yardımıyla incelenmiş ve balistik deney sonuçlarıyla karşılaştırllmıştır. Zırh sisteminde seramik ön yüzey için $10 \mathrm{~mm}$ kalınlı̆̆ında Alümina $\left(\mathrm{Al}_{2} \mathrm{O}_{3}\right)$ altıgen seramikler kullanılmış ve arka yüzey için S235JR çeliğinden üretilmiş $6 \mathrm{~mm}$ kalınlı̆̆ında plaka tercih edilmişstir. Analitik hesaplamalarda çelik plakada oluşan deformasyona ait sehim eğrisi matematiksel model yardımıyla hesaplanmıs ve Matlab programında gelişstirilen bir ara yüz ile çizdirilmiştir. Matematiksel modelin oluşturulmasinda toplam plastik gerinim enerjisi ve efektif gerilmegerinim denklemlerinden yararlanılmıştır. Çelik plakanın mermi darbesine karşı göstermiş olduğu balistik davranışın sayısal analizleri Ansys/Explicit Dynamic (17.1) sonlu eleman programında gerçekleştirilmiştir. Sayısal analizde çelik malzeme modeli olarak yüksek hizlarda plastik şekil değişimine imkân sağlayan Johnson-Cook malzeme modeli, seramik malzeme modeli olarak ise JohnsonHolmquist malzeme modeli seçilmiştir. Seramik ön yüzlü çelik zurh sisteminin balistik deneyleri, saylsal analiz modeline uygun olarak üretilen zırh numunesi

* Dr.Öğr.Üyesi, Kırıkkale Üniversitesi, Mühendislik Fakültesi, kalaycioglu@kku.edu.tr, ORCID ID: 0000-0002-1295-3816

**Dr.Öğr.Üyesi, Kırıkkale Üniversitesi, Mühendislik Fakültesi, alemdarongun@kku.edu.tr, ORCID ID: 0000-0002-7585-4305

Geliş Tarihi/Received : 17.04 .2020

Kabul Tarihi/Accepted : 21.09.2020

Araştırma Makalesi/Research Article DOI: $10.17134 /$ khosbd.913681 
üzerinde gerçekleştirilmiştir. Yapılan analizler sonucunda çelik plakada oluşan sehim ĕgrileri ve maksimum deformasyon değerleri deney sonuçlart ile ayr ayr karşılaştırılmıştır. Elde edilen sonuçlara göre tüm yöntemlerde sehim eğrilerinin uyum içinde olduğu, plakada oluşan maksimum deformasyon için analitik sonuçların \%15, sayısal sonuçların ise \%14 farkla deneysel sonuçlara yakınsadı̆̆ gözlemlenmistir.

Anahtar Kelimeler: Balistik, Tabakalı Zırh, Seramik Zırh, Johnson-Cook, S235JR, Yüksek Gerinim Hızı.

\title{
Investigation of Deformation of Steel Plate After Ballistic Damage in Ceramic Faced Steel Armor
}

\begin{abstract}
As being in many studies today, numerical analysis has become primarily preferred in armor design due to the scarcity of ballistic test opportunities and their high cost. However, the overlap of numerical analysis and experimental results is very important for the verification of numerical analysis. In this study, the plastic deformation condition on the steel plate on the back surface of the steel armor system with ceramic front face as a result of the $7.62 \mathrm{~mm}$ caliber bullet impact was investigated with the help of analytical and numerical analysis and compared with the results of ballistic experiments. In the armor system, $10 \mathrm{~mm}$ thick Alumina $\left(\mathrm{Al}_{2} \mathrm{O}_{3}\right)$ hexagonal ceramics are used for the ceramic front surface and $6 \mathrm{~mm}$ thick plate made of S235JR steel is preferred for the rear surface. In analytical calculations, the deflection curve of the deformation occurring in the steel plate was calculated with the help of a mathematical model and was drawn with an interface developed in the Matlab program. Total plastic strain energy and effective stress-strain equations were used to construct the mathematical model. Numerical analysis of the ballistic behavior of the steel plate against the projectile impact was carried out in the Ansys / Explicit Dynamic finite element program. In numerical analysis, the Johnson-Cook material model, which enables plastic shape change at high speeds, was chosen as the steel material model, and the JohnsonHolmquist material model was chosen as the ceramic material model. Ballistic experiments of the ceramic faced steel armor system were performed on the armor sample produced in accordance with the numerical analysis model. As a result of the analysis, deflection curves and maximum deformation values on the steel plate
\end{abstract}


Seramik Ön Yüzlü Çelik Zırhlarda Balistik Hasar Sonrası Çelik Kısmında Oluşan Deformasyonun İncelenmesi

were compared with the experimental results. According to the results, it was observed that the deflection curves were compatible in all methods, and the analytical results were converted to the experimental results with a difference of $15 \%$ and numerical results with a $14 \%$ difference for maximum deformation in the plate.

Keywords: Ballistic, Layered Armor, Ceramic Armor, Johnson-Cook, S235JR, High Strain Rate.

\section{Giriş}

İnsanların ve askerî araçların korunmasında mühimmat teknolojilerinin gelişimi ile zırh sistemlerinin önemi daha da artmıştır. Birinci Dünya Savaş1 yıllarında özellikle savaş gemilerinde yüksek sertliğe sahip çelikler oldukça iyi balistik performans sağlamalarından dolayı zırhların temel malzemesi olarak tercih edilmiştir. Fakat çelik zırhlar tek başlarına gelişen savaş teknolojileri ile yeterli performansı sağlayamamışlardır. Günümüzde seramik malzemeler ile desteklenmiş yeni tip tabakalı zırh sistemleri çok daha dayanıklı olup geniş ölçekte kullanılır hale gelmiştir (Crouch, 2016).

"Balistique" Fransızcadan gelen, mermilerin namlu iç ve dış hareketlerini ve tahrip edilen hedef üzerindeki hasarını inceleyen bilim dalıdır (Candan, 2005). Atış bilimi diye de tabir edilen balistik, mermi ve füzelerin hareketlerini inceler ve beş bölüme ayrılır.

İç Balistik: Mermi veya füzenin silahta veya uygulanan yerdeki hareketini yani merminin tahrikini inceler. Merminin namluda ateşlendiği andan çıkışına kadar olan kısmı inceler (Army, 1965).

Namlu Ağzı Balistiği: Ara balistik olarak da bilinir, mermi namludan çıktıktan sonra arkasındaki basınç dengeleninceye kadar olan kısmını inceler (The Editors of Encyclopædia Britannica, 2017).

Dış Balistik: Mermi ya da füzenin uçuş sırasında hareketi inceler.

Terminal Balistik: Merminin hedef üzerindeki etkilerini ve davranışlarını inceler (Zook vd., 1992).

Yara Balistiği: Merminin canlı hedefe isabet ettiği, terminal balistik ile tıp alanının birleşimidir (Zook vd., 1992b). 
Terminal balistik, mermi ve hedef arasındaki etkileşimi inceleyen balistiğin bir alt koludur. Terminal balistik, binalarda, tanklarda, zirhlarda vb. meydana gelen tüm darbe etkilerini, kinetik enerji dönüşümlerini, kimyasal enerji dönüşümlerini, patlayıcı etkisini araştıran bilim alanıdır. Şekil 1'de görüldüğü üzere, mermi hedefe çarptı̆̆ dalgalar seviyelerine bağlı olarak elastik, plastik veya sadece şok dalgaları şeklinde olabilir.
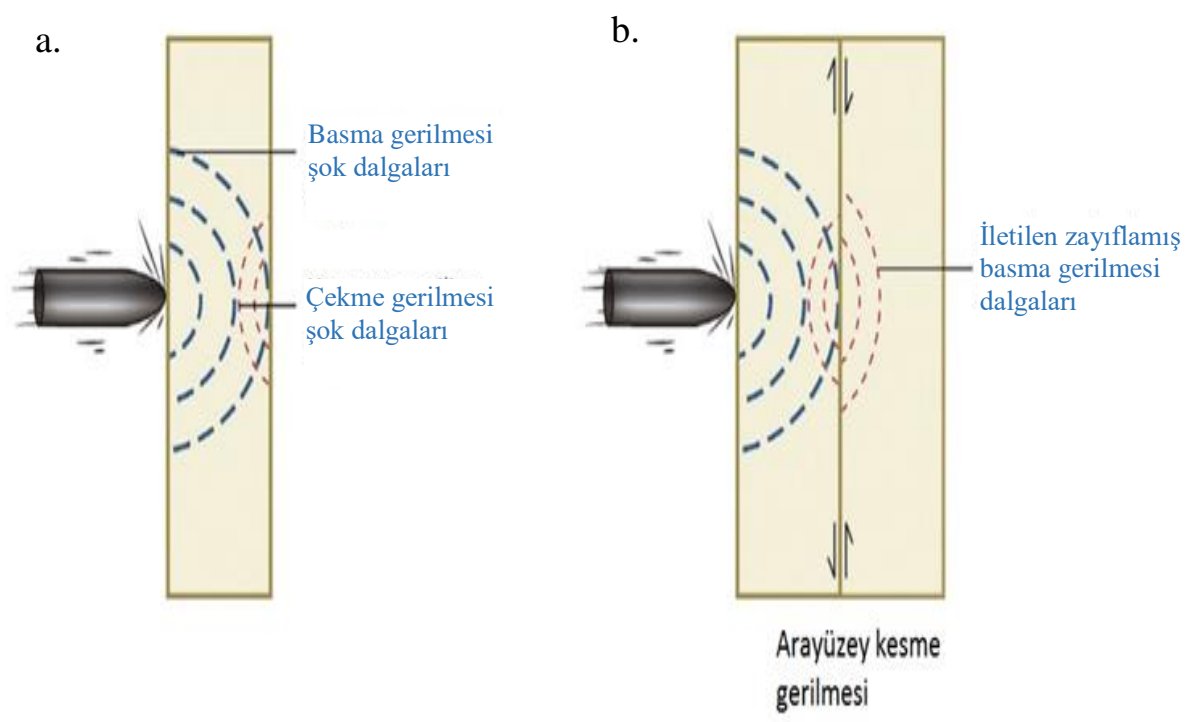

Şekil 1. a. Basma ve Çekme Gerilmesi Şok Dalgalarının Yayılması b. Herhangi Bir Ara Yüzeyde İletilen Zayıflamış Basma Gerilmesi Dalgaları İle Kesme Gerilmesi

(Crouch, 2016)

Mermilerin zırh üzerinde verdiği hasar çeşitlerini anlayarak; zırhın ne kadar enerji absorbe edebildiği ve mermiyi ne kadar hasara uğratıp, merminin enerji dağılımını ne oranda yaptığını fark ederek incelemek balistik için önemli bir konudur. Bu sebeple mermilerin zırh üzerinde oluşturduğu hasar (penatrasyon) mekanizmalarını sekiz başlıkta inceleyebiliriz. Delinme, kesilme (zımpa tipi), deleminasyon (tabakalar arası ayrılma), konik, radyal ve çevresel çatlaklar, mekanik disk atma, şok dalgası disk atma ve şarapnel etkisi. 
Seramik Ön Yüzlü Çelik Zırhlarda Balistik Hasar Sonrası Çelik Kısmında Oluşan Deformasyonun İncelenmesi

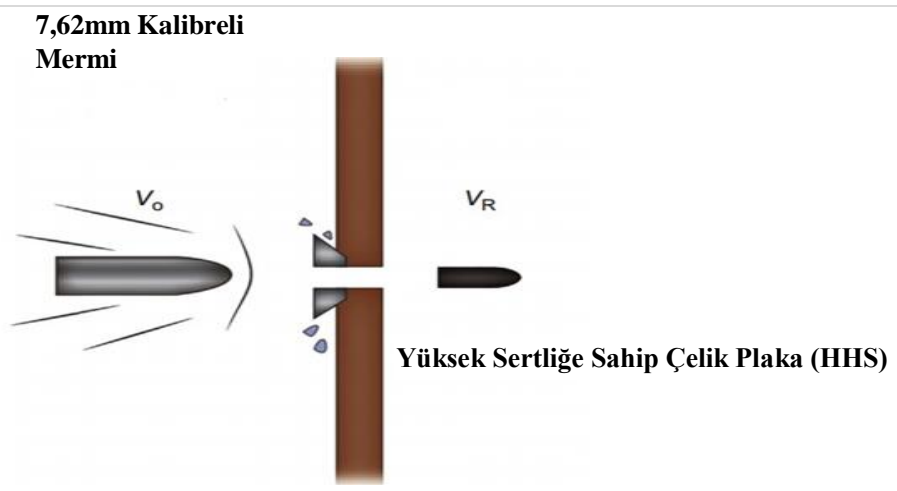

Şekil 2. Tek Katmanlı Çelik Zırh Sistemi (Crouch, 2016)

\section{Zırh Sistemlerinin Tasarımı}

Zırh sistemlerinin tasarımında izlenecek yöntemler tek katmanlı çelik zırh sistemlerden, çok katmanlı ve farklı malzemelerin kullanıldığı karmaşık yapılı zırh sistemlerine gidildikçe farklılıklar içermektedir. Ancak ister basit ister karmaşık yapılı olsun, mühendislik çalışmalarında delinmeyen veya mühimmatın oluşturduğu hasarı korunan bölgeye geçirmeyen bir zırh sisteminin tasarlanabilmesi için mutlaka balistik testlerin yapılması gerekmektedir.

\subsection{Tek Katmanlı Celik Bir Zırh Sisteminin Tasarımı}

Malzemesi yüksek sertliğe sahip olarak seçilen çeliğin, atış testlerinde merminin zırh yüzeyine dik geldiği tek katmanlı çelik bir zırh sisteminin 7,62 mm kalibreli mermiye karşı tam koruma sağlaması için gerekli zırh kalınlığının hesaplanmasında $V_{D}$ mermi tasarım hızının belirlenmesi gerekmektedir. Bu amaçla yapılan Şekil 2'de şematize edilmiş balistik atış testleri yardımıyla tek katmanlı çelik zırh sisteminde 7,62 mm kalibreli merminin zırhı hasara uğratma olasılı̆̆ 1 merminin zırha çarpma hızına bağlı olarak Şekil 3'te bir fonksiyon olarak verilmiştir. Şekil 2'de $\mathrm{V}_{0}$ merminin zırh sistemine çarpma hızını, $\mathrm{V}_{\mathrm{R}}$ ise zırhı delip geçtikten sonra mermide kalan hızı ifade eder. Ayrıca, Şekil 3'teki eğrinin normal kümülatif dağılım fonksiyonuna benzediği görülmektedir. Normal dağılımdaki ortalama nokta, Şekil 3'te $\mathrm{V}_{50}$ hızı olarak alınmış olup bu hız değerinde tek katmanlı çelik zırh sistemi $\% 50$ oranında delinmiştir. Yine normal dağılımın standart sapması (sigma) Şekil 3'te belirsiz bölgenin (gri bölge) ne kadar geniş olduğunun bir ölçüsüdür. $\mathrm{V}_{50}$ hızının altında ve üzerinde kalan alanlar belirsiz 
bölge (gri bölge) olarak geçmekte ve altı sigma yardımıyla belirlenmektedir. $\mathrm{V}_{50}$ hızının altındaki mermi hızlarında zırhın hasara uğrama olasılığı azalmakta, $V_{50}$ hızının üzerindeki mermi hızlarında ise hasar olasılığı artmaktadır. Belirli bir hız limitine geldiği anda zırh mutlak olarak hasara uğramaktadır. Bu durum $\mathrm{P}=1$ olduğunda karşılaşılan durumdur.

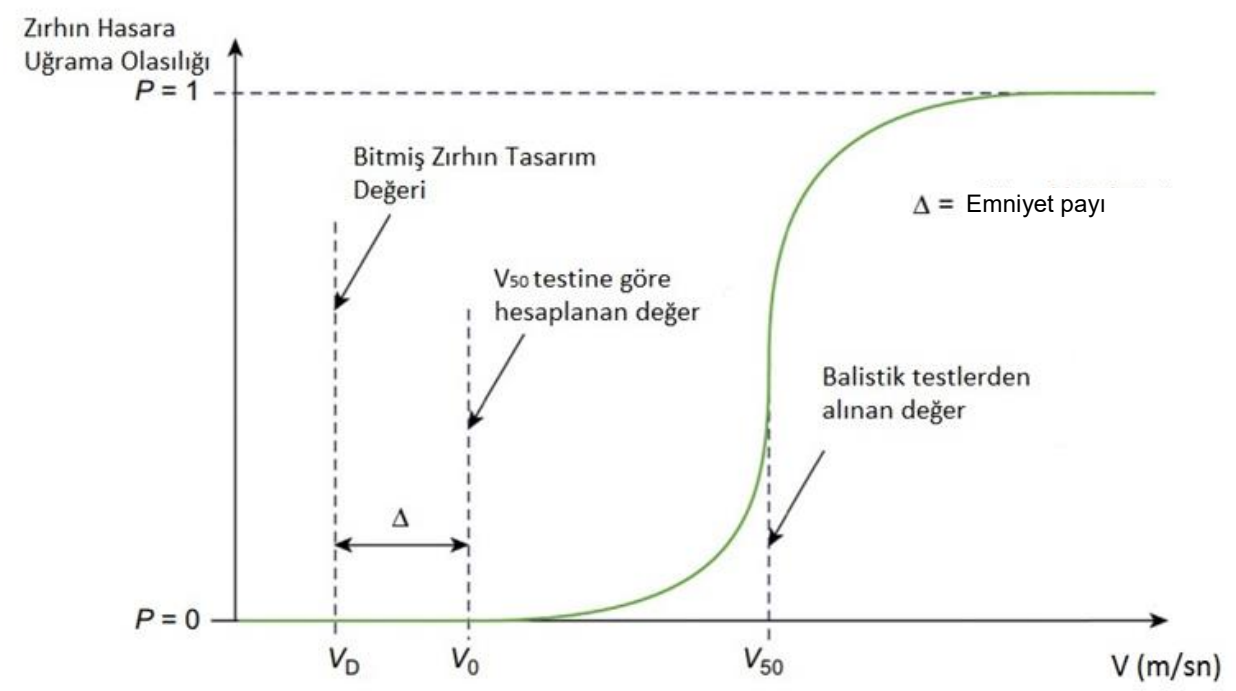

Şekil 3. Merminin Zırha Çarpma Hızına Bağlı, Zırhın Delinme İhtimalinin Grafik Gösterimi (Crouch, 2016)

Yine Şekil 3'te gösterilmiş $V_{0}$ çarpma hızında yapılan deneylerde atışların neredeyse tamamında zırha herhangi bir delinme görülmez. Ancak mühendisler güvenliği garanti edebilmek için $\mathrm{V}_{0}$ hızınında altına inerler. Emniyet payı olarak isimlendirilen $(\Delta)$ hız değerini $V_{0}$ hızından düşerek $V_{D}$ hızını elde ederler ve bu hız değerini tehdit olarak alıp, tasarımlarını $\mathrm{V}_{\mathrm{D}}$ hızına göre yaparlar. $(\Delta)$ hız değerinin büyüklüğü, tasarımcıların uygulancak güvenilirlik derecesine ile arzu edilen en düşük ağırlık çözümüne bağlı olarak belirlenecektir. Şekil 3’te P değeri zırhın hasara uğrama olasılığını göstermektedir. Balistik atış deneyleri yapılırken en kötü senaryonun uygulanması gerekmektedir. Bu sebeple merminin zırh düzlemine dik olarak çarptığı durum dikkate alınmaktadır.

Terminal balistikte altı sigma yardıyla bulnan gri bölge, zırh sisteminin ne kadar kompleks yapılı olduğunu veya ne kadar uygun zırh malzemesi olduğunun 
Seramik Ön Yüzlü Çelik Zırhlarda Balistik Hasar Sonrası Çelik Kısmında Oluşan Deformasyonun İncelenmesi

mükemmel bir ölçüsüdür. Tek katmanlı çelik zırh sistemi gibi basit zırh sistemlerinde gri bölge oldukça dar $(5 \mathrm{~m} / \mathrm{sn}$ 'den daha az), kompleks yapılı zırh sistemlerinde ise gri bölge oldukça geniştir $(50 \mathrm{~m} / \mathrm{s})$. Seramik içeren zırh sistmelerinde altı sigma mikro yapıdaki kusurların sayısına bağlıdır. Katmanlı kompozit kumaş içeren yumuşak yapılı zırh sistemlerindeki gri bölgenin genişliği kompozit kumaşın üretildiği malzemenin ne kadar iyi olduğunun (dikiş kalitesi, örgü deseni veya elyaf mukavemeti) bir ölçüsü olarak alınabilir.

a.

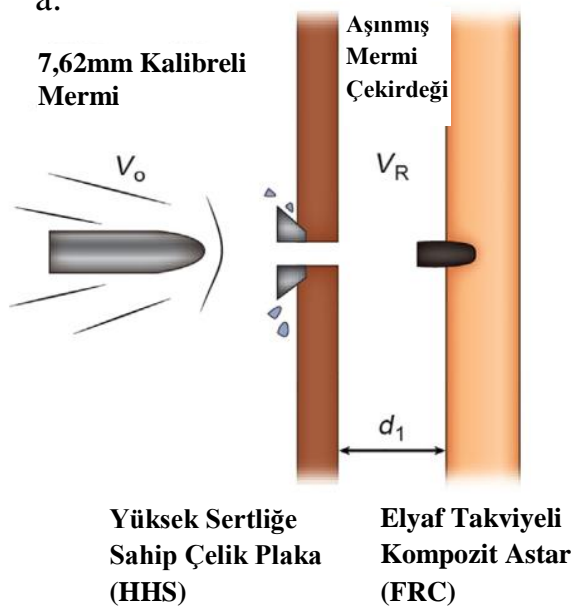

b.

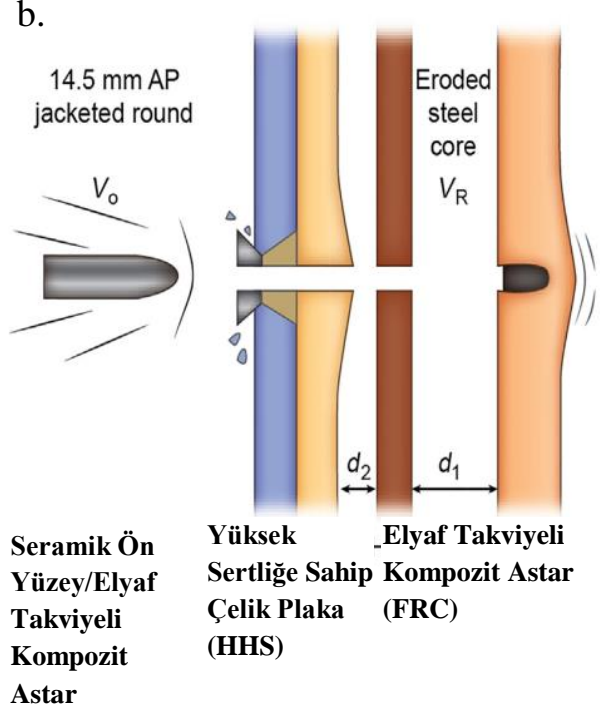

Şekil 4. a. Tek Katmanlı Çelik Zırh Sistemine Elyaf Takviyeli Kompozit (FRC) Bir Astarın Eklenmesi b. Seramik Ön Yüze Sahip Elyaf Takviyeli Kompozit (FRC) Astarlı Çelik Zırh Sistemi (Crouch, 2016)

\section{2. Çok Katmanlı Zırh Sistemlerinin Tasarımı}

Bir önceki örneğe göre tehdit seviyesinin yükseldiği durumlarda zırh üreticileri zırh malzemesinin yapısını iyileştirmek zorunda kalırlar. Tasarımcılar çelik zırhın arka tarafına elyaf takviyeli kompozit (FRC) bir astar yerleştirerek şok dalgasının zırhta meydana getirdiği deformasyon sonucu kopup yüksek hızlara ulaşmış, yaralayıcı ve öldürücü hale gelebilen, küçük boyutlardaki kırılmış zırh ve mühimmat parçalarının korunan bölgeye geçmesini engellemiştir. 
Şekil 4 (a)' da gösterilmiş geliştirilmiş zırh sistemi 14,5 mm kalibreli bir mermiye maruz bırakıldığında daha fazla iyileştirilmeye ihtiyaç duyacaktır. Bu durumda Şekil 4 (b)' de gösterildiği gibi zırh sisteminde mevcut çelik plakanın ön yüzeyine seramik bir malzeme konularak iyileştirme ihtiyacına bir çözüm getirilmiştir. Seramik ön yüzeye sahip çelik zırh sistemlerinde seramik ön yüzey, merminin sahip olduğu kinetik enerjinin önemli bir kısmını absorbe etmektedir. Seramiğin sert yapısı merminin deforme olmasına ve kütle kaybına da neden olmaktadır. Merminin kinetik enerjisinin büyük kısmı zırh sistemine ait çelik plaka tarafindan emilmektedir. Bu durum da çelik zırh plakasının plastik deformasyona uğramasına neden olmaktadır.

Zırh sistemlerinde gerçekleştirilecek olan bütün bu iyileştirmeler zırhın tasarımda gerekli tüm kriterlerin ve değişkenlerin artmasına neden olmaktadır.

Yazında çelik zırhlar veya seramik ve/veya kompozit takviyeli çelik zırh sistemlerinin davranışını inceleyen birçok çalışma yapılmıştır. Bu çalışmaları özetlemek gerekirse, Al-Qureshi ve Ishikura (1998), seramik ön yüzlü çelik zırh sisteminin çelik kısmında oluşan deformasyon miktarını öngörebilmek için yaptıkları bir çalışmada, deneysel ve analitik yöntemlerden faydalanmışlardır. 5,56 $\mathrm{mm}$ kalibreli mermi darbesi sonucu alüminyum plakada exponansiyel bir plastik deformasyon eğrisinin oluştuğu Şekil 5'te gösterilmiştir. Deneylerden faydalanarak analitik bir formül geliştirmişlerdir.

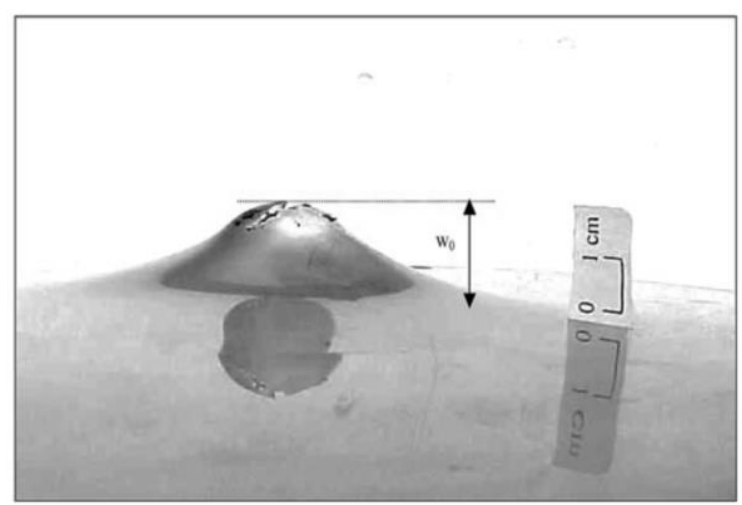

Şekil 5. Metal Plakanın Plastik Deformasyonu ve Maksimum Deformasyonu (AlQureshi \& Ishikura, 1998) 
Seramik Ön Yüzlü Çelik Zırhlarda Balistik Hasar Sonrası Çelik Kısmında Oluşan Deformasyonun İncelenmesi

Iqbal ve arkadaşları (2016), $8 \mathrm{~mm}$ ve $10 \mathrm{~mm}$ kalınlığındaki Armox 500T malzemeye farklı sicaklıklarda, 7,62 mm ve $12,7 \mathrm{~mm}$ API mermiler kullanarak yaklaşı $830 \mathrm{~m} / \mathrm{s}$ hızlarında balistik atış testleri yapmışlardır. Bu sayede Armox 500T çelik malzemesini farklı gerilme, gerinim ve sıcaklıklarda balistik olarak incelemişlerdir. Çalışmada zırh delici mermi (Armor Piercing Incendiary Projectile-API) kullanmışlardır. Deney sonuçlarında; termal hassasiyetinin yüksek olduğu, sıcaklık arttıkça mukavemetinin düştüğü, kırılma gerinim hızının azaldığ1 görülmüştür.

Wang ve arkadaşları (2013), yaptıkları çalışmada, malzeme karakteristiklerinin belirlenmesini ve mermi ve hedef arasındaki etkileşimi anlatmaya çalışmışlardır. Çalışmada yenilikçi hafif hibrit kompozit plakalarda kullanılan alümina seramik peletleri, ultra yüksek molekül ağırlıklı polietilen (UHMWPE), ve çift katman Ti-6Al-4V (TC4) malzemeyle tasarlamışlardır. Mermi hızı ortalama $818 \mathrm{~m} / \mathrm{s}$ olan $12,7 \mathrm{~mm}$ API mermiler kullanmışlardır. Çalışmalarındaki alümina \%99,7 saflığa sahip olup, peletin bombe yarıçap ve genişliği oranı $0,85: 1$ ve $1,28: 1$ şeklindedir. Çalışmalarının sonucunda yeni bir tasarımla üretilen ve ağırlığın azaltıldığı zırhın mermiyi yeterli ölçüde sönümlediği, enerjisini absorbe edebildiği gözlenmiştir.

Tria \& Trębiński (2017), kuramsal modelleri deneysel olarak doğrulayarak yeni bir yöntem geliştirmek üzerine çalışmışlardır. Küçük silahlardan çıkan mühimmatın oluşturduğu terminal balistiğini incelemek üzere nümerik algoritmalar kullanmışlardır. Metodolojileri, bir dizi bağımsız testle malzeme modellerinin tanımlanması, terminal balistikte önemli olan mermi-hedef etkileşimlerini incelemek için yeterli veri sağlamaktır. Deneylerde ölçülen verilerle düzgün bir model oluşturabilmek için parametrelerin doğru değerlendirilmesi ile sapmaların karakterize edilmesini sağlamaktır. Çalışmada 7,62 mm API mermi ve hedef olarak etki hızında delinebilecek çelik plaka kullanmışlardır. Ls-Dyna programında sonlu elemanlar kodları kullanarak basit, karmaşık kuramsal modelleme ve çarpma sonrası terminal analizleri yapılmıştır. Hedefte ve mermide bulunan farklı balistik sonuçlar, katı Lagrange ve hibrid kat1/gerçek parçacıklar hidrodinamiği (SPH) ayrılma yöntemlerinde kullanılan sonuçlarla karşılaştırılmıştır. Oluşturdukları model deneysel sonuçlar için iyi bir yaklaşım oluşturmakta ve bazı fiziksel mekanizmaların tahmininde kullanılabilmektedir. Geliştirilen model mermi 
penetrasyon mekanizmasını ve plakanın çarpışmadan sonraki hasarını, plakanın eğilme miktarını, tıkanmayı, şişmeyi ve mermide oluşan deformasyonu ve kırılmayı tahmin edilebilir kılmıştır.

Iqbal ve arkadaşları (2012), yaptıkları bir başka çalışmada ise mermi şeklinin ve mermi giriş açısının balistik limitlerini ve tahrip mekanizmasını incelemişlerdir. Kurşun şeklini ve kurşunun tahrip edilecek numuneye giriş açısını değişik olasilıklarda sonlu elemanlar metoduyla modelleyerek, ABAQUS programında analizlerini gerçekleştirmişlerdir. $12 \mathrm{~mm}$ kalınlığında Weldox $460 \mathrm{E}$ hedefe, $20 \mathrm{~mm}$ çelik kurşun, 6 farklı mermi ucu açısı $\left(33,4^{\circ}, 60^{\circ}, 90^{\circ}, 120^{\circ}, 150^{\circ}\right.$ ve $\left.180^{\circ}\right)$ ve 5 farklı giriş açısıyla $\left(0^{\circ}, 15^{\circ}, 30^{\circ}, 45^{\circ}, 60^{\circ}\right)$ oluşan hasarı ön ve arka yüzeyleri dikkate alarak incelemişlerdir. Mermi ucundaki açının değişimine bağlı darbenin yol açtığı hasar tartışılmış, yazında var olan diğer nümerik ve analitik model sonuçlarıyla karşılaştırmalar yapılmış ve sonuçların oldukça yakın olduğu görülmüştür. Merminin ön ilk değen kısmının açısının artışıyla beraber hedefin genel deformasyonunda azalma görülmüştür. Bilgisayarda ABAQUS/Explicit modülünde yapılan analizler JC modeline göre yapılıp, analitik olarak hesaplanmıştır.

\section{Johnson-Cook Malzeme Modeli}

Johnson-Cook (JC) malzeme modeli yüksek gerinim hızlarında ve sıcaklıklarda metal malzemelerin gerilme - şekil değişimi ilişkisini tahmin etmek için kullanılmaktadır (Kılıç, 2014). JC malzeme modelinin ampirik olarak elde edilen denklem (1)'de gösterilen matematiksel ifadesi incelendiğinde, ilk kısmın statik yük altındaki metal malzemenin davranışını, ikinci kısım gerinim hızına bağl1 pekleşme durumunu, üçüncü kısım ise malzemenin yüksek sıcaklıktaki termal yumuşama durumunu ifade etmektedir. Denklemde $\sigma$ [MPa] efektif akma gerilmesini, $\varepsilon_{p l}$ efektif plastik birim şekil değişimeyi, $\dot{\varepsilon}_{\mathrm{pl}}\left[\mathrm{s}^{-1}\right]$ efektif plastik birim gerinim hızını ve $\dot{\varepsilon}_{0}\left[\mathrm{~s}^{-1}\right]$ statik çekme deneyinde birim gerinim hızını ifade etmektedir. Ayrıca A, B ve n parametreleri metal malzemenin statik çekme deneyi ile elde edilmektedir. C, $\dot{\varepsilon}_{p l}, \dot{\varepsilon}_{0}$ ve m parametreleri ise yüksek gerinim hızlarında yapılan çekme deneyleri yardımıyla elde edilmektedir (Verleysen vd, 2011).

$\sigma=\left(\mathrm{A}+\mathrm{B} \varepsilon_{\mathrm{pl}}^{\mathrm{n}}\right)\left(1+\mathrm{C} \ln \left(\frac{\dot{\varepsilon}_{\mathrm{pl}}}{\dot{\varepsilon}_{0}}\right)\right)\left(1-\left[\frac{\mathrm{T}-\mathrm{T}_{\mathrm{r}}}{\mathrm{T}_{\mathrm{m}}-\mathrm{T}_{\mathrm{r}}}\right]^{\mathrm{m}}\right)$ 
Bu çalışma, balistik deney imkânlarının azlığ 1 ve bir hayli maliyetli olması sebebiyle sayısal analiz sonuçlarının balistik deney sonuçlarına ne kadar yakınsadığını göstermek amacıyla yapılmıştır. Çalışmada, uygun malzemelerle geliştirilmiş seramik ön yüze sahip çelik zırh sisteminde 7,62 mm kalibreli mermi darbesinin zırh sisteminin çelik arka yüzeyinde yapmış olduğu plastik deformasyon sayısal ve analitik yöntemlerle hesaplanmış ve daha sonra çıkan sonuçlar deneysel sonuçlar ile karşılaştırılmıştır. Analitik hesaplamalarda çelik plakada oluşan deformasyona ait sehim eğrisi toplam plastik gerinim enerjisi ve efektif gerilmegerinim denklemlerinden yararlanılarak elde edilen bir matematiksel model yardımıyla hesaplanmıştır. Çelik plakanın mermi darbesine karşı göstermiş olduğu balistik davranışın sayısal analizleri Ansys ${ }^{\circledR} /$ Explicit Dynamic (17.1) sonlu eleman programında gerçekleştirilmiştir. Sayısal analizde çelik malzeme modeli olarak yüksek hızlarda plastik şekil değişimine imkân sağlayan Johnson-Cook malzeme modeli, seramik malzeme modeli olarak Johnson-Holmquist malzeme modeli seçilmiştir. Elde edilen sonuçlara göre tüm yöntemlerde sehim eğrilerinin uyum içinde olduğu, plakada oluşan maksimum deformasyon için analitik sonuçların $\% 15$, sayısal sonuçların ise $\% 14$ farkla deneysel sonuçlara yakınsadığ 1 gözlemlenmiştir.

\section{Teorik Çalışmalar}

$\mathrm{Bu}$ çalışmada 7,62 mm kalibreli mermi darbesi sonucu zırhın çelik kısmında oluşan plastik deformasyon eğrisi Matlab programında geliştirilen bir matematiksel model yardımıyla analitik olarak hesaplanmıştır. Matematiksel modelin oluşturulmasında, toplam plastik gerinim enerjisi ve efektif gerilmegerinim denklemlerinden yararlanılmıştır. Bahsi geçen denklemlerden analitik yöntem başlığı altında detaylı olarak bahsedilmiştir. Daha sonra analitik olarak hesaplanan çelik plakaya ait plastik deformasyon eğrisi, Ansys ${ }^{\circledR} /$ Explicit Dynamic 17.1 sonlu eleman programında yapılan balistik sayısal analiz sonuçlarıyla karşılaştırılmıştır.

\section{Analitik Yöntem}

Metal zırhlarda mermi darbesine maruz metal plakadaki gerilme-gerinim durumunun, hidrolik şişirme testi uygulanan bir metal plakanın gerilme-gerinim durumuna benzediği varsay1lır (Hosford ve Caddell, 2011). Hidrolik şişirme testi altındaki bir plakadan alınan gerilme elemanında oluşan gerilme durumu Şekil 6'da 
gösterilmiştir. Plakadaki gerilme durumunun düzlem gerilme durumunda oluştuğu ve küresel basınç kaplarındaki gerilme durumuna benzer olarak her iki eksendeki gerilmelerin birbirine eşit olduğu ve üçüncü eksendeki gerilmenin sıfir olduğu kabul edilmektedir (düzlem gerilme durumu) (Hosford, 2010). Bahsi geçen düzlem gerilme durumuna ait gerilmeler denklem (2) ve (3)'te ifade edilmiştir. Aynı gerilme elemanında bir ve iki eksenlerinde oluşan $\varepsilon_{1}$ ve $\varepsilon_{2}$ gerinimleri birbirine eşittir. Üçüncü eksende oluşan $\varepsilon_{3}$ gerinimi ise plastik bölgede hacim değişmezliği prensibinden $\varepsilon_{1}$ ve $\varepsilon_{2}$ gerinimlerinin tam tersi yönünde ve her iki gerinimin toplamına eşit olarak elde edilir. Denklem (4), (5) ve (6)'da bu eşitlikler gösterilmiştir.

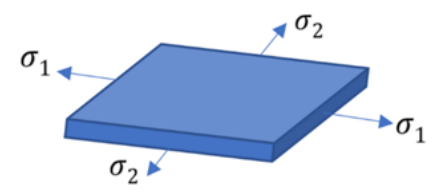

Şekil 6. Birim Eleman Gösterimi

$\sigma_{1}=\sigma_{2}=\sigma ; \quad \sigma_{3}=0$

$\sigma=\frac{P * r}{2 * t_{d}}$

$\varepsilon_{1}+\varepsilon_{2}+\varepsilon_{3}=0$

$\varepsilon_{1}=\varepsilon_{2}=\varepsilon$

$\varepsilon_{3}=-2 \varepsilon$

(5) ve (6) denklemlerinden elde edilen gerinimler (7) numaralı von-Mises efektif gerinim denklemine yazılmış ve düzlem gerilme durumundaki plakaya ait (8) denkleminde verilen efektif gerinim değeri elde edilmiştir.

$$
\begin{aligned}
& \bar{\varepsilon}=\sqrt{\frac{2}{9}\left\{\left(\varepsilon_{1}-\varepsilon_{2}\right)^{2}+\left(\varepsilon_{2}+\varepsilon_{3}\right)^{2}+\left(\varepsilon_{3}-\varepsilon_{1}\right)^{2}\right\}} \\
& \bar{\varepsilon}=2 \varepsilon=-\varepsilon_{3}
\end{aligned}
$$

Yanal yüklemeler altında küçük yer değişimine uğramış eğilmeye maruz bir plakada oluşan gerinimler Şekil 7'de verilen AB doğrusal elemanı yardımıyla hesaplanmıştır. Doğru parçasına ait x yönündeki gerinim (9) numaralı denklem ile 
Seramik Ön Yüzlü Çelik Zırhlarda Balistik Hasar Sonrası Çelik Kısmında Oluşan Deformasyonun İncelenmesi

ifade edilmiştir. Şekil 7'deki geometride AB doğrusal elemanında oluşan şekil değişimi (9) denkleminde yazılırsa, aşamalı olarak (11) numaralı denklem elde edilir. (12) numaralı denklemde yer alan $\frac{\partial u}{\partial x}$ ifadesi, küçük şekil değişimlerinden dolayı ihmal edilmiştir.

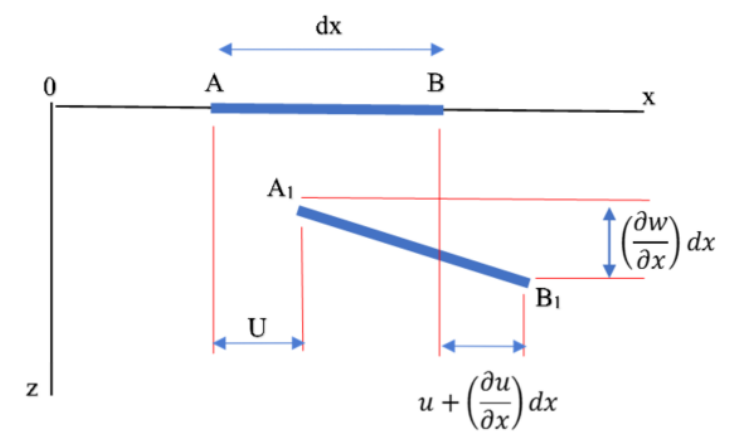

Şekil 7. Şekil Değişiminin Geometrik Gösterimi (Timoshenko S., 1959)

$\varepsilon_{x}=\frac{\Delta l}{l}=\frac{A^{1} B^{1}-A B}{A B}=\frac{A^{1} B^{1}-d x}{d x}$

$A^{1} B^{1}=d x+d x \varepsilon_{x}$

$\left(A^{1} B^{1}\right)^{2}=\left(d x\left(1+\varepsilon_{x}\right)\right)^{2}=\left(d x+\frac{\partial u}{\partial x} d x\right)^{2}+\left(\frac{\partial w}{\partial x} d x\right)^{2}$

$2 \varepsilon_{x}=2 \frac{\partial u}{\partial x}+\left(\frac{\partial w}{\partial x}\right)^{2}$

$\varepsilon_{x}=\frac{\partial u}{\partial x}+\frac{1}{2}\left(\frac{\partial w}{\partial x}\right)^{2}$

$\varepsilon_{x}=\varepsilon_{r}=\frac{1}{2}\left(\frac{\partial w}{\partial r}\right)^{2}$

Holloman gerilme-gerinim bağıntısı (15) numaralı denklemle ifade edilir. "A" mukavemet katsayısı, " $n$ " pekleşme üsteli olmak üzere plastik gerinim enerjisi denklemi yukarıdaki denklemlerle birleştirildiğinde plastik şekil değişiminin genel denklemi, aşağıdaki gibi elde edilir.

$$
\begin{aligned}
& \overline{\boldsymbol{\sigma}}=\mathbf{A}(\overline{\boldsymbol{\varepsilon}})^{\mathbf{n}} \\
& \mathbf{E}_{\mathbf{p}}=\int\left(\int_{\mathbf{0}}^{\bar{\varepsilon}} \overline{\boldsymbol{\sigma}} \boldsymbol{\partial} \overline{\boldsymbol{\varepsilon}}\right) \mathbf{d V}
\end{aligned}
$$


$E_{p}=\frac{A}{n+1} \int(\bar{\varepsilon})^{n+1} d V$

Bunun yanı sıra (17) numaralı denklemin çözümü için metal plakada gerçekleşen şekil değişiminin mermiye bağlı profilinin bilinmesi gerekmektedir. $\mathrm{Bu}$ şekil değişim formunun eksponansiyel olarak yaklaşımını (18) numaralı denklemde; "wo" merminin etkisi bittiği anda kubbede oluşan maksimum yer değiştirme (merminin uç kısmının çarptığı noktada oluşan yarıçap), "r" maksimum deformasyona olan yatay uzunluk, "w" r'ye bağlı uzunlukta oluşan deformasyon, "D" mermi yarıçapı, " $\mathrm{V}_{\mathrm{i}}$ " mermi hızı deneysel olarak bulunan " $\mathrm{k}$ " gerinim profili sabiti olmak üzere (18) ve (19) numaralı denklemlerden (20) numaralı denklemi elde edilir ve devamındaki denklemlerde görüldüğü üzere sadeleştirilir. (22) numaralı eşitlikte yer alan B, genel denklemleri sadeleştirmek için oluşturulmuş bir ifadedir. Sonuç olarak (24) numaralı merkezde oluşan maksimum deformasyon miktarını veren denklem elde edilir.

$$
\begin{aligned}
& \mathbf{w}=w_{0} \exp \left[-\frac{k r}{D}\right] \\
& \frac{\partial w}{\partial r}=\frac{-w_{0} \exp (-k r / p) k}{D} \\
& E_{p}=\frac{2 \pi h A}{n+1} \int\left(\frac{k w_{0} e^{\frac{-k r}{D}}}{D}\right)^{2(n+1)} r \partial r \\
& E_{p}=\frac{\pi h A}{2(n+1)^{3}} \frac{k^{2 n_{n_{0}}}}{D^{2 n}} \\
& B=\frac{\pi h A}{2(n+1)^{3}}\left(\frac{k}{D}\right)^{2 n} \\
& E_{p}=\frac{1}{2} m v_{i}^{2}=B\left(w_{0}^{2(n+1)}\right) \\
& w_{0}=\left[\frac{m v_{i}^{2}}{2 B}\right]^{\frac{1}{2(n+1)}}
\end{aligned}
$$

Maksimum sehim miktarı "wo" bulunduktan sonra deneysel çalışmalar sonucu elde edilen ve deneylerle kıyaslanarak olumlu sonuçlar alınan sehim profilinin oluşturulmas gerekmektedir. Merminin çarptığı noktaya bağl1, istenilen uzaklığa göre hesap edilmesi gereken sehim miktarı (18) numaralı denklemle elde edilir. Denklem exponansiyel olarak önceki çalışmalar göz önünde bulundurularak 
Seramik Ön Yüzlü Çelik Zırhlarda Balistik Hasar Sonrası Çelik Kısmında Oluşan Deformasyonun İncelenmesi

çıkarılmıştır (Al-Qureshi ve Ishikura, 1998). Denklemde "wo" merminin çarptığ nokta, maksimum sehim noktası olup kenara gittikçe bu sehim exponansiyel olarak azalmaktadır.

Yukarıda elde edilen denklemler yardımıyla çelik plakanın plastik deformasyonuna ait sehim eğrisini hesaplayan matematiksel model Matlab programında geliştirilen bir arayüze dönüştürülmüştür. Matematiksel modelde, profil sabiti, pekleşme üsteli, mermi çapı, plaka kalınlığı ve malzeme mukavemet değerleri gibi parametreler yer almaktadır. Şekil 8 'de gösterilmiş olan arayüze bahsi geçen parametreler girildiğinde, mermi darbesine maruz çelik plakada oluşan plastik deformasyona ait sehim eğrisi, exponansiyel olarak elde edilmektedir.

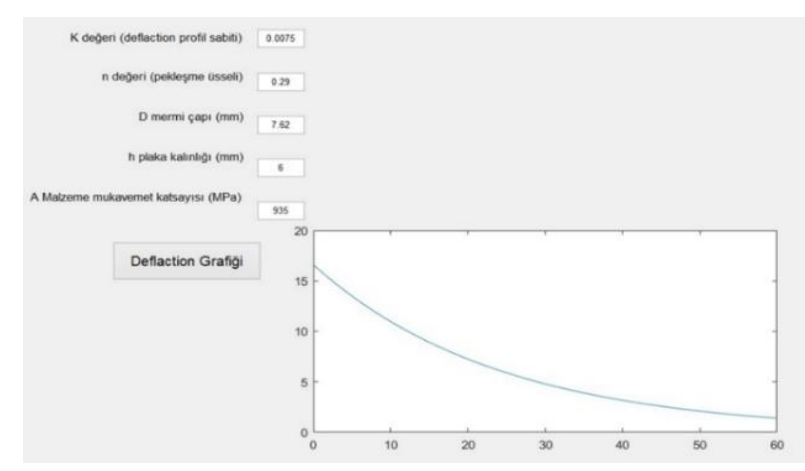

Şekil 8. Matlab Programında Geliştirilen Arayüz

Sayısal Analiz

Bu bölümde 7,62 mm kalibreli mermi darbesi sonucu seramik ön yüzlü çelik zırh sisteminin çelik plakasında oluşan plastik deformasyon Ansys ${ }^{\circledR} /$ Explicit Dynamic 17.1 sonlu eleman programında incelenmiştir. Zırh sisteminin modellenmesinde altıgen seramiklerin malzemesi Alümina seramik olarak seçilmiş ve seramik kalınlığı $10 \mathrm{~mm}$ olarak alınmıştır. Zırh sisteminde plastik deformasyonu elde edebilmek için çelik plaka malzemesi olarak Armox zırh çeliği yerine çok daha sünek yapıda olan S235JR malzemesi seçilmiş ve plaka kalınlığı $6 \mathrm{~mm}$ olarak belirlenmiştir. Yapılan modellemede 7,62 mm kalibreli mermi darbesine maruz kalan merkezdeki seramiğin çevresi Şekil 9 (a)'da görüldüğü üzere altı adet seramikle çevrelenmiştir. Şekil 9 (b)'de gösterilen 7,62 mm kalibreli ve $25 \mathrm{~mm}$ boyundaki mermi, analizlerde ilk mermi darbesine maruz kalan seramiğin tam 
ortasına noktasal temas şeklinde modellenmiştir. NIJ - 0108.01 (1985) standardına göre 7,62 mm kalibreli AP mermi hızı 838 $\pm 15 \mathrm{~m} / \mathrm{sn}$ olarak alınmıştır.

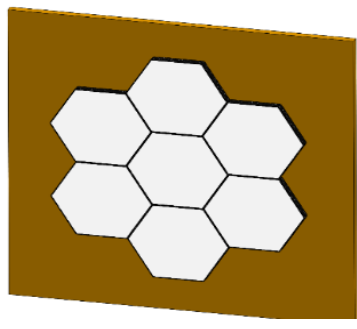

a.

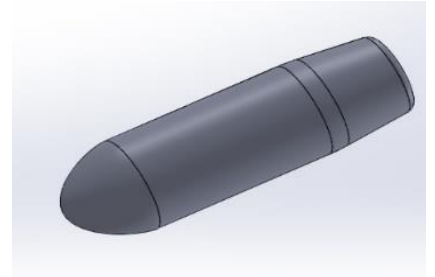

b.

Şekil 9. a. Çelik Üzerinde Alümina Seramiklerin Görünümü b. Mermi Görünümü

Seramik ön yüze sahip çelik zırh sistemine ait sayısal analiz modelinde 280.548 düğüm noktası ve 216.423 ağ elemanı kullanılmıştır. Modelde kullanılan ağ yapısının eleman sayısı belirli oranlarda arttırılmış olup, mesh sayısının sonuca etkisinin kalmadığı durumdaki hali seçilmiş ve böylelikle analizleri optimum sürede çözmek hedeflenmiştir. Modelde Alümina seramikler 3 boyutlu, 20 dügümlü, yapı analizi özellikli solid 186, tetrahedral mesh elemanıyla, çelik plaka ise solid 186, hexahedral mesh elemanı ile modellenmiş olup zırh sisteminin mesh modeli Şekil 10'da verilmiştir. Çelik plaka için seçilen eleman yapısı plastisite, büyük yer değiştirme ve büyük gerinim özelliklerini desteklediğinden dolayı tercih edilmiştir (ANSYS® ${ }^{\circledR}$ 17.1 User Manual). Mermi darbesine maruz Alümina seramik ön yüzlü çelik zırh sisteminin balistik sayısal analizinde Alümina seramikler, S235JR çelik plaka yüzeyine yapışık kontak durumunda tanımlanmıştır.

Çelik malzeme modeli olarak yüksek hızlarda plastik şekil değişimine imkân sağlayan Johnson-Cook malzeme modeli, seramik malzeme modeli olarak Johnson-Holmquist malzeme modeli kullanılmıştır. Zırh sisteminde yer alan malzemelere ait mekanik özelliklerin bir kısmı Tablo 1'de verilmiştir. 
Seramik Ön Yüzlü Çelik Zırhlarda Balistik Hasar Sonrası Çelik Kısmında Oluşan Deformasyonun İncelenmesi

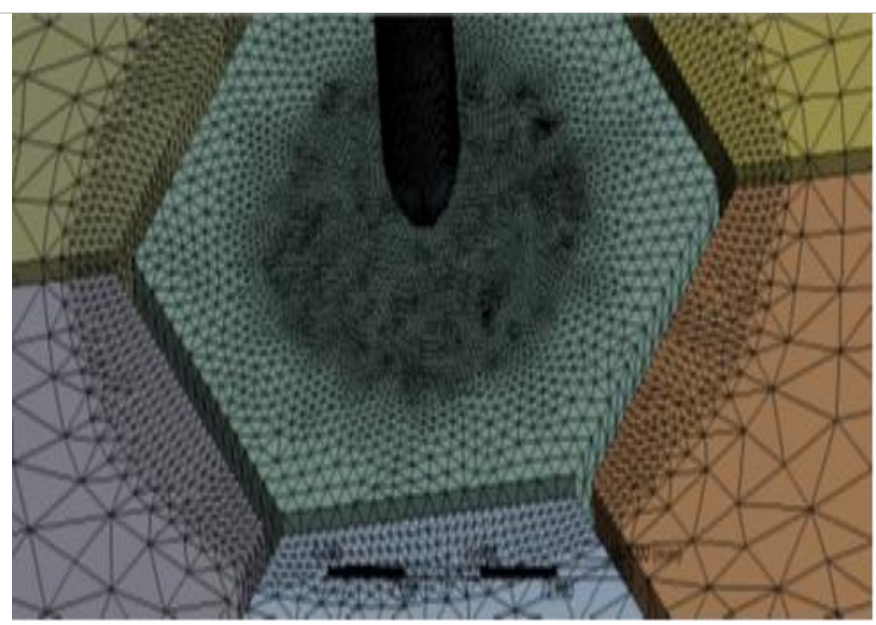

Şekil 10. Zırh Siztemine Ait 7,62 mm Kalibreli Merminin Merkezdeki Seramiğin

Tam Ortasına Konumlandırılmış ve Meshlere Ayrılmış Sonlu Eleman Modeli

Tablo 1. Malzeme Özellikleri

\begin{tabular}{llll}
\hline & Mermi & Seramik & S235JR \\
\hline Özkütle $\left(\mathrm{kg} / \mathrm{m}^{3}\right)$ & 11340 & 3900 & 7840 \\
Akma Gerilmesi $(\mathrm{MPa})$ & 140 & & 235 \\
Elastisite Modülü $(\mathrm{GPa})$ & 14 & 370 & 210 \\
Sertlik $(\mathrm{HV})$ & & 1600 & \\
\hline
\end{tabular}

Çalışmada yapılan sayısal analizde kullanılan S235JR çeliğine ait JohnsonCook parametreleri Tablo 2'de verilmiştir.

Tablo 2. Analizde Kullanılan JC Çelik Malzeme Modeline Ait Parametre Değerleri (Verleysen vd, 2011)

\begin{tabular}{|c|c|c|c|c|c|}
\hline$A[\mathrm{MPa}]$ & $B[\mathrm{MPa}]$ & $n$ & $C$ & $\dot{\varepsilon}_{0}\left[\mathrm{~s}^{-1}\right]$ & $m$ \\
\hline 280 & 667 & 0,72 & 0,071 & 1 & 0,269 \\
\hline
\end{tabular}

Deneysel Çalışmalar

Zırh sisteminin balistik atış testleri deney poligonunda toplam 6 adet olacak şekilde gerçekleştirilmiştir. Bu kapsamda NIJ - 0108.01 Seviye 3'e göre koruma seviyesi referans alınıp, seviyenin belirttiği mermilerle $838 \pm 15 \mathrm{~m} / \mathrm{sn}$ 
hızlarında tek mermi atışı yapılmıştır. Balistik atış deneylerin de NATO-STANAG 2310 (1976) standardını sağlayan Makine ve Kimya Endüstrisi Kurumu tarafından üretilen 7,62 mm kalibreli mermiler kullanılmıştır. Şekil 11'de deneylerde kullanılan zırh sistemine ait deney numunesi gösterilmiştir. Zırh sisteminin ön yüzeyinde bulunan 7 adet Alümina seramik 404 marka özel katalizörlü plastikçelik yapıştırıcısı kullanılarak arkadaki çelik plakaya yapıştırılmıştır.

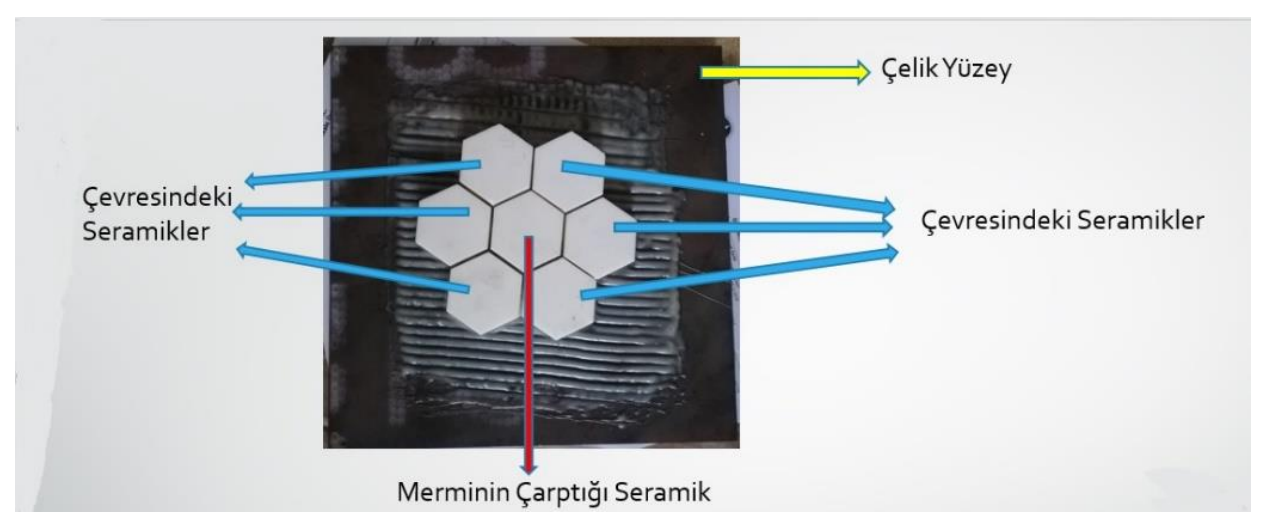

Şekil 11. Zırh Sistemine Ait Deney Numunesi

Atış testlerinde Şekil 12'de görüldüğü üzere merkezde bulunan seramiğin orta noktasına lazerle nişan alınmış ve sabit namlu tarafından atışlar gerçekleştirilmiştir.

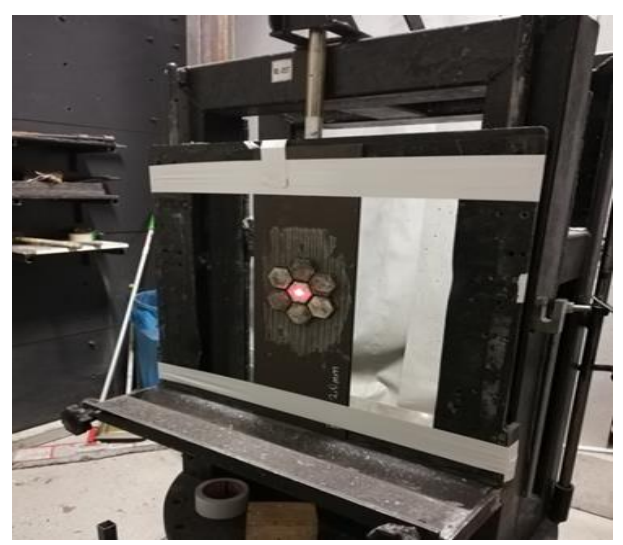

Şekil 12. Seramik Ön Yüzlü Çelik Zırhın Balistik Test İçin Hazırlanan Düzeneğe Yerleştirilmesi 
Seramik Ön Yüzlü Çelik Zırhlarda Balistik Hasar Sonrası Çelik Kısmında Oluşan Deformasyonun İncelenmesi

Yapılan deneylerde 7,62 mm kalibreli mermilerin zırh sistemine çarpma hızları iki farklı ölçüm cihazından alınmıştır. Ölçüm cihazlarından alınan mermi hızları ve ortalama hız değerleri Tablo 3 'te verilmiştir.

Tablo 3. Farklı Ölçüm Cihazından Alınan Ölçümler ve Ortalama Çarpma Enerjileri

\begin{tabular}{cccc}
\hline Atış Numarası & 1. Ölçüm Cihazı & 2. Ölçüm Cihazı & Ortalama Hız (m/sn) \\
\hline 1 & 843,45 & 839,73 & 841,59 \\
2 & 844,27 & 842,93 & 843,60 \\
3 & 841,45 & 837,37 & 839,41 \\
4 & 843,84 & 843,55 & 843,70 \\
5 & 840,78 & 841,94 & 841,36 \\
6 & 842,14 & 839,18 & 840,66 \\
\hline
\end{tabular}

Atış testleri sonucunda her bir deney numunesinde meydana gelen çelik plakalara ait maksimum deformasyon değerleri Tablo 4'te verilmiştir.

Tablo 4. Çelik Yüzeyde Oluşan Maksimum Deformasyonlar

\begin{tabular}{cccccc}
\hline $\begin{array}{c}\text { 1. Deney } \\
(\mathrm{mm})\end{array}$ & $\begin{array}{c}\text { 2. Deney } \\
(\mathrm{mm})\end{array}$ & $\begin{array}{c}\text { 3. Deney } \\
(\mathrm{mm})\end{array}$ & $\begin{array}{c}\text { 4. Deney } \\
(\mathrm{mm})\end{array}$ & $\begin{array}{c}\text { 5. Deney } \\
(\mathrm{mm})\end{array}$ & $\begin{array}{c}\text { 6. Deney } \\
(\mathrm{mm})\end{array}$ \\
\hline 14,98 & 14,78 & 14,65 & 14,94 & 14,85 & 15,02 \\
\hline
\end{tabular}

\section{Analiz Sonuçları ve Tartışma}

Bu bölümünde seramik ön yüzlü çelik zırh sistemine gelen mermi darbesi sonrası zırhın arka kısmında yer alan çelik plakanın plastik deformasyonu analitik ve sayısal analizler yardımıyla hesaplanmış daha sonra deneysel sonuçlarla karşılaştırılmıştır. Çalı̧̧manın diğer kısmında zırh sistemine gelen mermi darbesinin S235JR çelik plakada meydana getirdiği von Mises efektif plastik gerilme ve birim şekil değiştirme durumu da incelenmiştir.

\section{1. Çelik Plakanın Plastik Deformasyonu}

Yapılan balistik sayısal analizlerden zırh sistemine gelen mermi darbesi sonrası S235JR çelik plakada oluşan plastik deformasyon durumu Şekil 13'te gösterilmiştir. Analiz sonucunda çelik plakada maksimum 12,74 mm'lik bir yer değiştirmenin meydana geldiği tespit edilmiştir. 


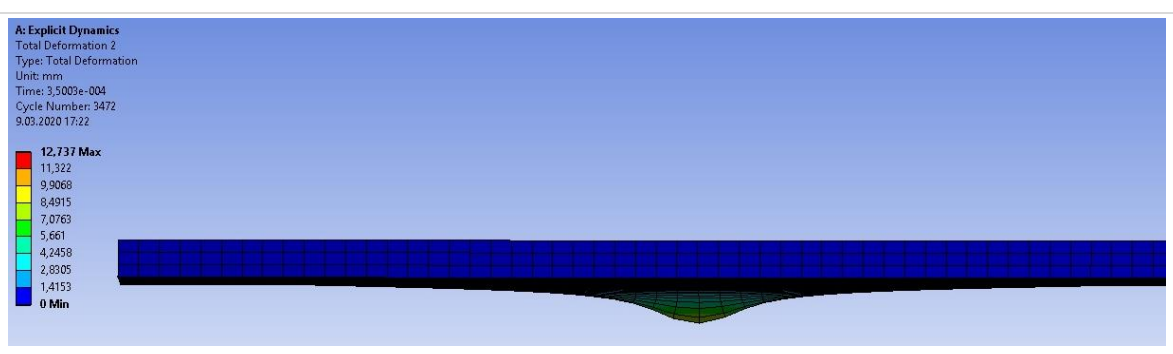

Şekil 13. Çelik Plakada Sayısal Analiz Sonucu Oluşan Plastik Deformasyon Durumu

Sonrasında yapılan balistik deneyler sonucu çelik plakada meydana gelen plastik deformasyon durumu Şekil 14'te gösterilmiştir. Yapılan deneylerden zırh sistemine ait çelik plakada maksimum yer değiştirme değeri $14,87 \mathrm{~mm}$ olarak ölçülmüştür.

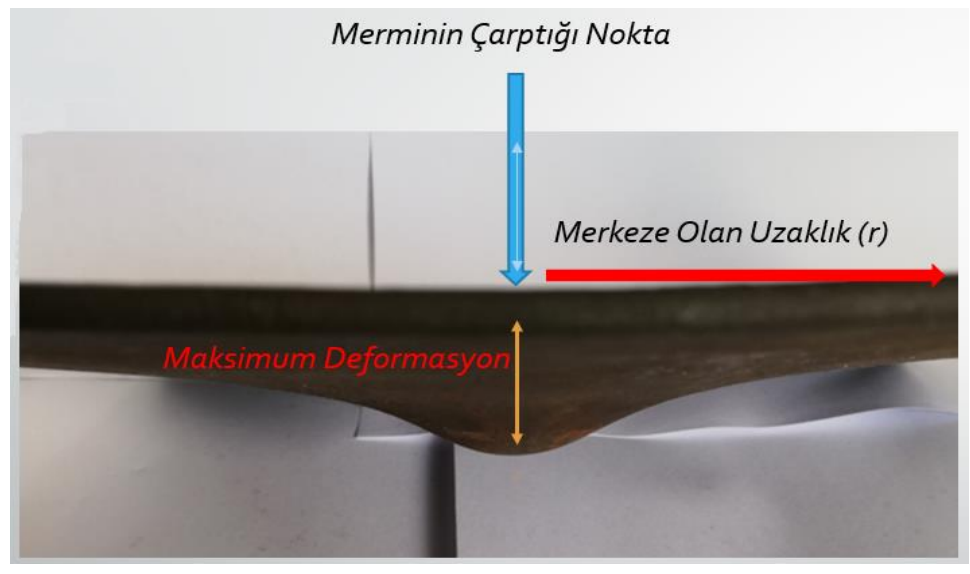

Şekil 14. Balistik Atıştan Sonra Çelik Görüntüsü ve İncelenen Değerlerin Gösterimi

Çelik plakaya ait sehim eğrisi için analitik çözüm, toplam plastik gerinim enerjisi ve efektif gerilme-gerinim denklemlerinden yararlanılarak bulunmuş gerinim denklemleri kullanılarak Matlab' da yazılan bir program yardımıyla elde edilmiştir. Analitik, sayısal ve deneysel yöntemlerle bulunmuş çelik plakanın plastik plastik deformasyonuna ait sehim eğrileri Şekil $15^{\prime}$ te verilmiştir. Sehim eğrilerindeki maksimum yer değiştirmeler incelendiğinde; deneysel sonucun 14,87 $\mathrm{mm}$, analitik sonucun $17,11 \mathrm{~mm}$ ve sayısal analizden elde edilen sonucun 12,74 
Seramik Ön Yüzlü Çelik Zırhlarda Balistik Hasar Sonrası Çelik Kısmında Oluşan Deformasyonun İncelenmesi

mm olduğu görülmektedir. Elde edilen sonuçlara göre analitik sonuçların $\% 15$ ve sayısal sonuçların ise \%14 farkla deneysel sonuçlara yakınsadığı belirlenmiştir.

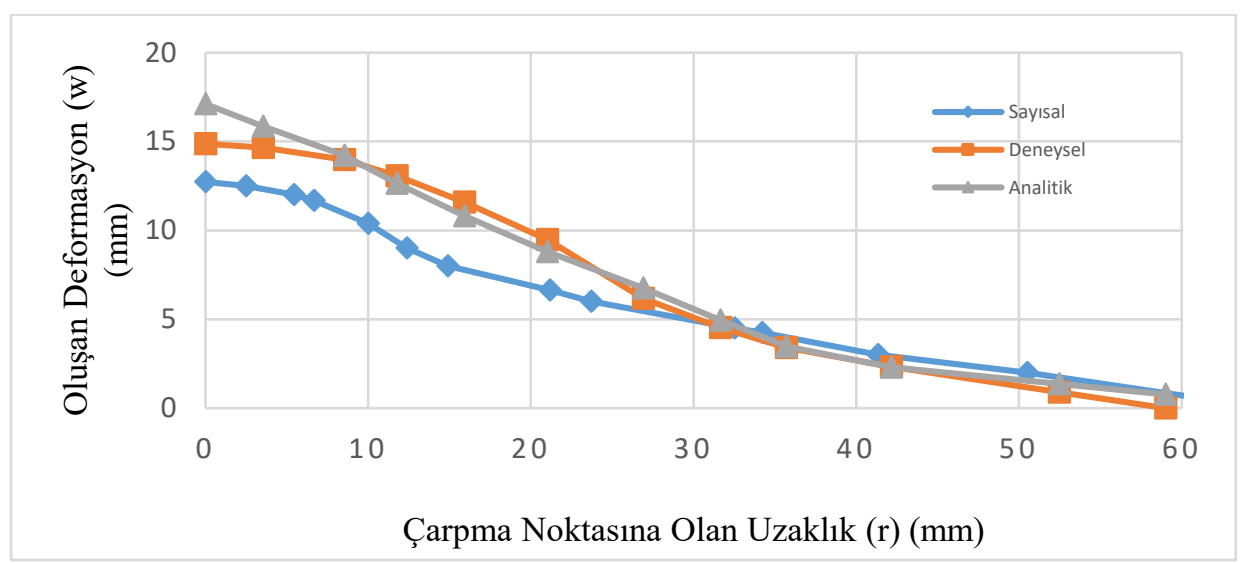

Şekil 15. Sayısal, Deneysel ve Analitik Deformasyon Eğrilerinin Karşılaştırılması

\section{2. Çelik Plakada Oluşan Gerilme Durumu}

Çalışmanın bu kısmında zırh sistemine gelen mermi darbesi sonucu S235JR çelik plakada oluşan plastik von Mises efektif gerilme durumu incelenmiştir. Öncelikle zırhın çelik plakasında mermi darbesi sonucu oluşan maksimum plastik von Mises efektif gerilme durumu yapılan balistik analiz sonucu $698 \mathrm{MPa}$ olarak bulunmuş ve Şekil 16'da gösterilmiştir.

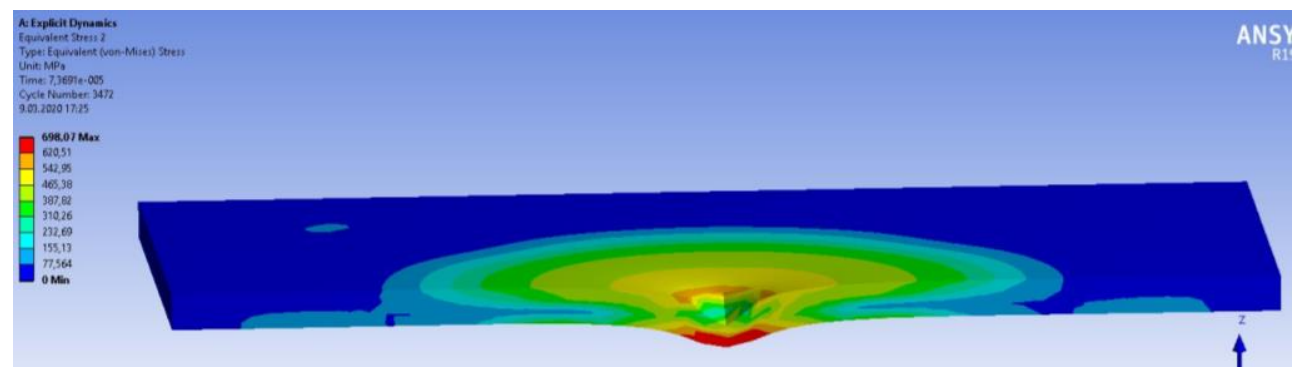

Şekil 16. Çelik Plakada Oluşan Von Mises Efektif Gerilme Durumu

Daha sonra balistik sayısal analiz sonucunda çelik plakada oluşan maksimum plastik von Mises gerilme değerinin, plaka malzemesi S235JR çeliğinin, plakanın maruz kaldığı yüksek gerinim hızında sahip olduğu akma 
dayanımı ve maksimum kuvvete maruz kaldığı andaki gerçek gerilme değerleri ile karşılaş̧ırması yapılmıştır.

Mermi darbesine maruz zırh sistemine ait çelik plakanın plastik deformasyonu yüksek gerinim hızında meydana gelmektedir. Metal malzemelerin yüksek hızlardaki gerinim hızlarında sahip oldukları dayanım değerleri statik yük altında sahip oldukları dayanım değerlerine göre artış göstermektedir. Bu durum malzemelerde birim gerinim hızı oranı etkisi olarak bilinmektedir (Hosford ve Caddell, 2011). Bu bağlamda zırh sistemine ait S235JR çelik plakasının mermi darbesi boyunca sahip olacağı yüksek gerinim hızında malzeme dayanım değerlerinin statik gerinim durumuna göre artış göstereceği ve balistik analiz sonucunda oluşan gerilme durumunun malzemenin bu yeni dayanım değerleri ile kıyaslanması gerektiği düşünülmektedir.

Terminal balistik çalışmalarında mermi darbesine maruz kalan hedef plakanın sahip olduğu yaklaşık gerinim hızı $\dot{\varepsilon}_{p}$ denklem 25'te gösterildiği gibi, merminin plakaya çarpma hızının Vp, mermi çapına Dm oranı ile bulunmaktadır (Cazamias ve Bless, 1997).

$\dot{\varepsilon}_{p}=\frac{V_{p}}{D_{m}}$

Yapılan başka bir (Goncalves vd., 2004) deneysel çalışmada çelik plakada ki plastik deformasyonun merminin çelik plakaya çarpması ile başladığını gözlemlemişlerdir. Bundan dolayı plakanın çekil değiştirme hızının bulunmasında merminin çelik plakaya çarptığı andaki hızı dikkate alınmıştır. Bu çalışmada yapılmış olan balistik sayısal analizde mermi, zırh sisteminin seramik ön yüzüne yaklaşık $838 \mathrm{~m} / \mathrm{s}$ hızla çarpmaktadır. Çarpışma sonrası seramik ön yüz parçalanmakta ve mermi belirli bir kinetik enerji kaybı ile çelik plakaya çarpmaktadır. Sayısal analizden merminin plakaya çarpma hızı $V_{p}=322,3 \mathrm{~m} / \mathrm{s}$ olarak bulunmuştur. Mermi çapının $\mathrm{Dm}=7,62 \mathrm{~mm}$ olarak alındığında, çelik plakanın yaklaşık gerinim hızı $\dot{\varepsilon}_{p}=42.296,5 \mathrm{~s}^{-1}$ olarak bulunmuştur.

JC malzeme modeli yüksek hızlarda malzemelerin plastik gerilme-gerinim ilişkisini veren bir malzeme modelidir. Bu özelliği ile S235JR çeliğinin, plakanın maruz kaldığ $42.296,5 \mathrm{~s}^{-1}$ birim şekil değiştirme hızında dinamik gerilme-birim şekil değiştirme ilişkisi yine S235JR çeliğinin pekleşme parametreleri kullanılarak JC malzeme modeli yardımıyla Şekil 17'de çizilmiştir. Aynı grafikte yapılan diğer 
Seramik Ön Yüzlü Çelik Zırhlarda Balistik Hasar Sonrası Çelik Kısmında Oluşan Deformasyonun İncelenmesi

çalışmadan (Verleysen vd., 2011) alınmış olan S235JR çeliğinin JC malzeme modeli kullanılarak statik gerilme-birim şekil değiştirme ilişkisi de gösterilmiştir. Bahsi geçen referansta S235JR çelik malzemesine Split-Hopkinson testiyle birbirinden farklı yüksek hızlarda yapılan deneyler sonucunda S235JR çeliğinin 0,1 $\mathrm{mm} / \mathrm{mm}$ birim şekil değiştirme değerinde çekme dayanımı değerine ulaştığı tespit edilmiştir. Ayrıca referans çalışmada S235JR çelik malzemesi için birbirinden farklı yüksek şekil değiştirme hızlarında ki çekme dayanımı değerlerinin sürekli $0,1 \mathrm{~mm} / \mathrm{mm}$ birim şekil değiştirme değerinde meydana geldiği ve şekil değiştirme hızının artmasıyla çekme dayanımı anındaki şekil değiştirme değerinin değişmediği gözlemlenmiştir. $\mathrm{Bu}$ sonuçtan hareketle S235JR çeliğinin 42.296,5 $\mathrm{s}^{-1}$ şekil değiştirme hızında maksimum kuvvete maruz kaldığı andaki gerçek gerilme değerine yaklaşık $0,1 \mathrm{~mm} / \mathrm{mm}$ şekil değiştirmesinde ulaşacağ kabul edilmiştir.

Şekil 17'de görüleceği üzere S235JR çelik malzemesinin 42.296,5 s ${ }^{-1}$ şekil değiştirme hızında JC malzeme modeli yardımıyla çizdirilen plastik gerçek gerilme-birim şekil değiştirme grafiğinde (JC-Dinamik) malzemenin akma dayanımının $602 \mathrm{MPa}$ ve maksimum kuvvete maruz kaldığ 1 andaki gerilme değerinin $751 \mathrm{MPa}$ olduğu gözlemlenmiştir.

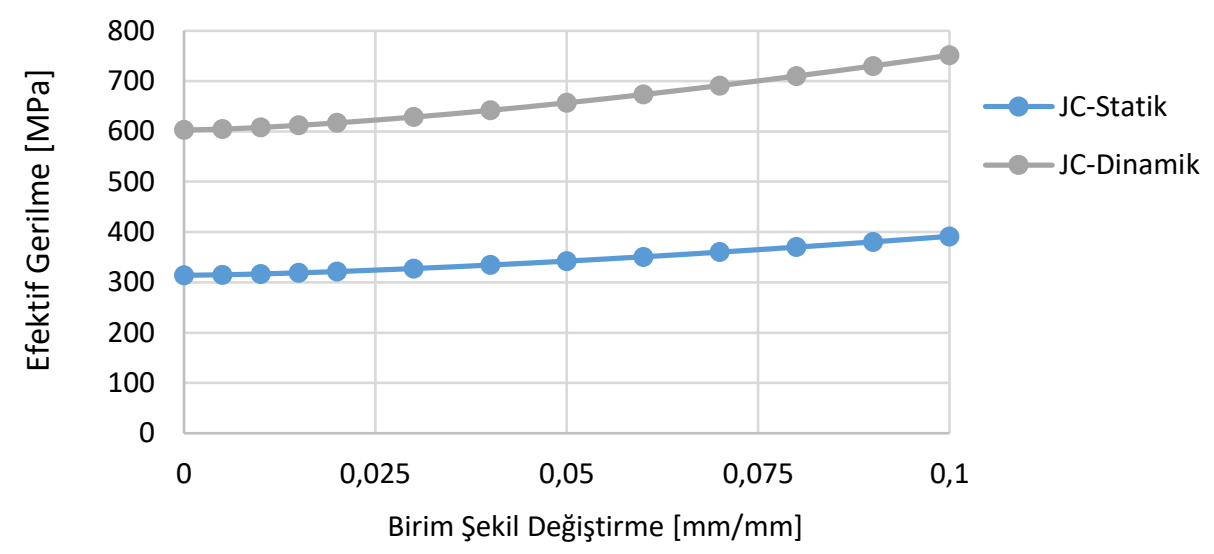

Şekil 17. JC Malzeme Modelinin Gerilme-Gerinim Grafiği

Zırh sisteminin balistik sayısal analizinde çelik plakada mermi darbesi sonucu maksimum $698 \mathrm{MPa}$ von Mises efektif plastik gerilmesinin oluştuğu, bu gerilme değerinde plakada herhangi bir delinme ve yırtılmanın oluşmadığı tespit edilmiş ve bu durum Şekil 16 'da gösterilmiştir. Bununla beraber sayısal analiz 
sonucunda plakada oluşan $698 \mathrm{MPa}$ von Mises efektif plastik gerilme değerinin yukarıda analitik olarak bulunan S235JR malzemesinin 42.296,5 $\mathrm{s}^{-1}$ gerinim hızında sahip olduğu akma dayanımı ve maksimum kuvvete maruz kaldığı andaki gerilme değerinin arasında kaldığı gözlemlenmiştir. Çelik plakada oluşan gerilme değerinin analitik olarak hesaplanmış malzemeye ait maksimum kuvvete maruz kaldığı andaki gerilme değerinin altında kalması, plakada sadece plastik deformasyonun oluşacağı ve herhangi bir delinme ve yırtılmanın oluşmayacağ anlamina gelmekte olup, bu durumun ayrica sayısal analiz sonucu ile de uyum sağladığı tespit edilmiştir. Bununla birlikte sayısal analizden elde edilen plakadaki herhangi bir hasarın oluşmadığı plastik deformasyon durumu Şekil 14'te gösterilen balistik deney sonucu ile de doğrulanmıştır.

\section{Sonuçlar}

Çalışmada seramik ön yüzlü çelik zırh sistemine gelen 7,62 mm kalibreli mermi darbesinin zırh sisteminin S235JR çelik plakasında meydana getirdiği plastik deformasyon durumu analitik, sayısal ve deneysel olarak incelenmiştir. Bununla birlikte zırh sisteminin S235JR çelik plakasında meydana gelen plastik von Mises efektif gerilme durumu da balistik sayısal analiz yardımıyla bulunmuş ve S235JR çelik malzemesinin yüksek gerinim hızlarında sahip olduğu dayanım değerleri ile karşılaştırılmıştır.

Yapılan çalışmalar neticesinde elde edilen sonuçlar aşağıda verilmiştir.

7,62 mm kalibreli mermi darbesi sonrası zırhın çelik plakasında oluşan plastik deformasyona ait maksimum yer değiştirme değeri; deneysel olarak 14,87 $\mathrm{mm}$, analitik olarak; $17,11 \mathrm{~mm}$ ve sonlu elemanlar analizinde $12,74 \mathrm{~mm}$ olarak tespit edilmiştir. Elde edilen sonuçlar irdelendiğinde analitik yaklaşım \%15, sonlu elemanlar analizi ise \%14'lük negatif sapma oranlarıla deneysel sonuçlara yakınsamıştır.

Bununla birlikte çelik plakaya ait deneysel, sayısal ve analitik olarak elde edilen sehim eğrilerinin birbirine yakın konumlarda olduğu gözlemlenmiştir. Elde edilen sonuçların birbiri ile uyumluluk göstermesi özellikle analitik ve sayısal analizlerin güvenilirliği noktasında önemli bir doğrulama olarak düşünülmektedir.

Zırh sisteminin balistik sayısal analizinde çelik plakada mermi darbesi sonucu maksimum $698 \mathrm{MPa}$ von Mises efektif plastik gerilmesinin oluştuğu, bu 
Seramik Ön Yüzlü Çelik Zırhlarda Balistik Hasar Sonrası Çelik Kısmında Oluşan Deformasyonun İncelenmesi

gerilme değerinde plakada herhangi bir delinme ve yırtılmanın oluşmadığı tespit edilmiştir.

S235JR çelik zırhının 42.296,5 $\mathrm{s}^{-1}$ şekil değiştirme hızında JC malzeme modeli yardımıyla çizdirilen plastik gerçek gerilme-birim şekil değiştirme grafiğinde (JC-Dinamik) malzemenin akma dayanımının $602 \mathrm{MPa}$ ve maksimum kuvvete maruz kaldığı andaki gerilme değerinin $751 \mathrm{MPa}$ olduğu gözlemlenmiştir.

Plakada meydana gelen $698 \mathrm{MPa}$ von Mises efektif plastik gerilme değerinin analitik olarak bulunan S235JR malzemesinin 42.296,5 $\mathrm{s}^{-1}$ gerinim hızında sahip olduğu akma ve çekme dayanımı değerlerinin arasında kaldığı gözlemlenmiştir. Çelik plakada oluşan gerilme değerinin analitik olarak hesaplanmış malzemeye ait maksimum kuvvete maruz kaldığı andaki gerilme değerinin altında kalması, plakada sadece plastik deformasyonun oluşacağ 1 ve herhangi bir delinme ve yırtılmanın oluşmayacağı anlamına gelmekte olup, bu durumun ayrıca sayısal analiz sonucu ve deney sonuçları ile de uyum sağladığı tespit edilmiştir.

\section{Extended Summary}

With the development of ammunition technologies in the protection of people and military vehicles, the importance of armor systems has increased. During the First World War, steels with high hardness were preferred as the basic material of armors, especially in warships, due to their very good ballistic performance. However, steel armors could not provide sufficient performance with war technologies developed alone. Today, new types of layered armor systems supported with ceramic materials have become much more durable and widely used.

As in many studies today, numerical analysis has become primarily preferred in armor design due to the scarcity of ballistic test opportunities and their high cost. However, how much numerical analysis converges to experimental results is very important. In this study based on this importance, the plastic deformation condition on the steel plate on the back surface of the steel armor system with ceramic front face as a result of the $7.62 \mathrm{~mm}$ caliber bullet impact was investigated with the help of analytical and numerical analysis and compared with the results of ballistic experiments. In the armor system, $10 \mathrm{~mm}$ thick Alumina 
$\left(\mathrm{Al}_{2} \mathrm{O}_{3}\right)$ hexagonal ceramics are used for the ceramic front surface and $6 \mathrm{~mm}$ thick plate made of S235JR steel is preferred for the rear surface.

In analytical calculations, the deflection curve of the deformation occurring in the steel plate was calculated with the help of a mathematical model and was drawn with an interface developed in the Matlab program. Total plastic strain energy and effective stress-strain equations were used to construct the mathematical model.

Numerical analysis of the ballistic behavior of the steel plate against the projectile impact was carried out in the Ansys / Explicit Dynamic finite element program. In numerical analysis, the Johnson-Cook material model, which enables plastic shape change at high speeds, was chosen as the steel material model, and the Johnson-Holmquist material model was chosen as the ceramic material model. In the analysis, 280.548 nodes and 216.423 mesh elements were used in the numerical analysis model of the steel armor system with ceramic front. The number of elements of the mesh structure used in the model has been increased at certain rates, and the state where the mesh number has no effect on the result is selected, and thus it is aimed to solve the analyzes in the optimum time. In the model, Alumina ceramics are modeled with three dimensional, 20 nodose solid 186 , tetrahedral mesh element with structure analysis feature, and steel plate is modeled with three dimensional, 20 nodose solid 186, hexahedral mesh element. The element structure chosen for the steel plate was preferred because it supports the plasticity, large displacement and large strain properties. (ANSYS ${ }^{\circledR}$ 17.1 User Manual). In the ballistic numerical analysis of the Alumina ceramic faced steel armor system exposed to the bullet impact, Alumina ceramics were defined in contact with the S235JR steel plate surface.

Ballistic tests of the armor system were carried out with a total of 6 pieces Alumina ceramic in the shooting test range. In this context, the protection level was taken as reference according to NIJ - 0108.01 Level 3 and a single shot was fired at $838 \pm 15 \mathrm{~m} / \mathrm{sec}$ velocities with the bullets specified by the level. $7.62 \mathrm{~mm}$ caliber bullets produced by the Machinery and Chemical Industry Corporation, which provides the NATO-STANAG 2310 (1976) standard, were used in ballistic tests.

As a result of the analysis, deflection curves and maximum deformation values on the steel plate were compared with the experimental results. According 
to the results obtained, it was observed that the deflection curves were compatible in all methods, and the analytical results converted to the experimental results with a difference of $15 \%$ and numerical results with a $14 \%$ difference for maximum deformation in the plate.

In the ballistic numerical analysis of the armor system, it was determined that maximum $698 \mathrm{MPa}$ von Mises effective plastic stress occurred in the steel plate as a result of the bullet impact, and no perforation and tearing occurred in the plate at this stress value. As a result of numerical analysis, it was observed that the effective plastic tensile value of $698 \mathrm{MPa}$ von Mises formed in the plate was between the yield strength of the S235 material found above analytically at the strain rate of $42,296.5 \mathrm{~s}^{-1}$ and the tensile value at the moment when it was exposed to maximum force. The fact that the stress value formed in the steel plate is below the stress value at the moment when it is subjected to the maximum force of the analytically calculated material means that only plastic deformation will occur in the plate and no perforation and tearing will occur, and this situation has also been found to be compatible with the numerical analysis result.

\section{Teşekkür}

$\mathrm{Bu}$ makale Kırıkkale Üniversitesi Bilimsel Araştırma Projeleri Koordinasyon Birimi tarafından desteklenmiş olup, bu desteğinden dolayı kendilerine teşekkür ederiz. Ayrıca balistik atış deneylerinde vermiş oldukları destekten dolayı Nurol Teknoloji A. Ş.' ye teşekkürü bir borç biliriz.

\section{Kaynakça}

\section{Kitaplar}

Army, U. (1965). Interior Ballistics of Guns. Engineering Design Handbook: Ballistics Series, United States Army Materiel Command.

Crouch, I. (2016). The science of armour materials. Woodhead Publishing.

Hosford, W.F. (2010). Solid mechanics. Cambridge University Press.

Hosford, W.F., \& Caddell, R.M. (2011). Metal forming: mechanics and metallurgy. Cambridge University Press.

The Editors of Encyclopædia Britannica. (2017). T.E.O.E. 
Gable Z., Hurley J., Chojnicki T. Wyka J., (2007). The Science of Ballistics, Physics 001, Lecture Note.

The Editors of Encyclopædia Britannica. (2017). T.E.o.E.

Timoshenko S., (1959), Theory of Plates and Shells, McGraw-Hill Book Company.

\section{Makaleler}

Al-Qureshi, H.A., \& Ishikura, D. (1998). Study of perforation of metals and composite materials paltes by projectile. Inżynieria Materiałowa, 19(3), 544-547.

Ballistic Resistant Protective Materials, (1985) NIJ Standard 0108.01. U.S., Department of Justice, National Institute of Justice, U.S. Department of Justice, Washington, DC 20531.

Candan, C. (2005). Kompozit zırh imalat parametrelerinin terminal balistik özellikler üzerine etkileri. Selçuk Üniversitesi, Konya.

Cazamias, J. U., \& Bless, S. J. (1997). Scaling effects in penetration: a Taylor test approach. Le Journal de Physique IV Colloque, 07 (C3), pp.C3-115-C3120.

Crouch, I. (2016). The science of armour materials. Woodhead Publishing.

Goncalves, D. P., De Melo, F. C. L., Klein, A. N., \& Al-Qureshi, H. A. (2004). Analysis and investigation of ballistic impact on ceramic/metal composite armour. International Journal of Machine Tools and Manufacture, 44(23), 307-316.

Iqbal, M.A., Diwakar, A., Rajput, A., \& Gupta, N.K. (2012). Influence of projectile shape and incidence angle on the ballistic limit and failure mechanism of thick steel plates. Theoretical and Applied Fracture Mechanics, 62, 40-53.

Iqbal, M.A., Senthil, K., Sharma, P., \& Gupta, N.K. (2016). An investigation of the constitutive behavior of Armox 500T steel and armor piercing incendiary projectile material. International Journal of Impact Engineering, 96, 146164.

Johnson, G.R., \& Cook, W.H. (1985). Fracture characteristics of three metals subjected to various strains, strain rates, temperatures and pressures. 
Seramik Ön Yüzlü Çelik Zırhlarda Balistik Hasar Sonrası Çelik Kısmında Oluşan Deformasyonun İncelenmesi

Engineering Fracture Mechanics, 21(1), 31-48.

Kılıç, N. (2014). Development of Multi-Layer Ballistic Armor Panel with Simulation and Ballistic Tests. Marmara University.

Small Arms Ammunition 7.62 mm, NATO - STANAG 2310, (1976).

Solid186, in ANSYS ${ }^{\circledR}$ Release 17.1, Help System, Mechanical APDL, Element Reference, Element Library: ANSYS, Inc.

Wang, Q., Chen, Z., \& Chen, Z. (2013). Design and characteristics of hybrid composite armor subjected to projectile impact. Materials \& Design, 46, 634-639

Tria, D.E., \& Trębiński, R. (2017). Methodology for experimental verification of steel armour impact modelling. International Journal of Impact Engineering, 100, 102-116.

Verleysen, P., Peirs, J., Van Slycken, J., Faes, K., \& Duchene, L. (2011). Effect of strain rate on the forming behaviour of sheet metals. Journal of Materials Processing Technology, 211(8), 1457-1464.

Zook, J.A., Frank, K., \& Silsby, G.F. (1992a). Terminal ballistics test and analysis guidelines for the penetration mechanics branch. Army Ballistic Research Lab Aberdeen Proving Ground.

Zook, J.A., Frank, K., \& Silsby, G.F. (1992b). Terminal Ballistics Test and Analysis Guidelines for the Penetration Mechanics Branch. U.S. Army Laboratory Command.

\section{Internet Kaynakları}

Gazi Fişek Fabrikas1, 7,62 mmx51 (M61) Zırh Delici Fişek. https://www. mkek.gov.tr/tr/product.aspx $? \mathrm{id}=52 \&$ source=Products $\&$ pid=738. 